University for Business and Technology in Kosovo

UBT Knowledge Center

Nov 7th, 9:00 AM - 5:00 PM

\title{
Christian Basilica, Serbian Orthodox Church or Ottoman Mosque? Some remarks on national monuments of sacral architecture
}

Caroline Jaeger-Klein

Technische Universität Wien, jaeger-klein@tuwien.ac.at

Follow this and additional works at: https://knowledgecenter.ubt-uni.net/conference

Part of the Architecture Commons

\section{Recommended Citation}

Jaeger-Klein, Caroline, "Christian Basilica, Serbian Orthodox Church or Ottoman Mosque? Some remarks on national monuments of sacral architecture" (2015). UBT International Conference. 64.

https://knowledgecenter.ubt-uni.net/conference/2015/all-events/64

This Event is brought to you for free and open access by the Publication and Journals at UBT Knowledge Center. It has been accepted for inclusion in UBT International Conference by an authorized administrator of UBT Knowledge Center. For more information, please contact knowledge.center@ubt-uni.net. 


\title{
Christian Basilica, Serbian Orthodox Church or Ottoman Mosque? Some remarks on national monuments of sacral architecture.
}

\author{
Caroline Jaeger-Klein \\ History of Architecture Vienna University of Technology \\ jaeger-klein@tuwien.ac.at
}

\begin{abstract}
The territories of Kosovo do hold quite a number of historic sacral monuments that several national entities call "their" architectural heritage. Can we really speak of a single nations' heritage in territories where, through the course of history, the politically leading or majority nation was shifted in place? To which nation does immoveable heritage belong, if the nation is no longer dwelling around the monument? Who takes care of such national heritage? Is heritage "national"? How can a national state administrate and manage architectural heritage that is not considered to be "his" national heritage?

Questions like those are current status for Kosovo nowadays. Answers are getting more urgent as the new state has to complete his new legislation within this or the next year(s). Kosovo hardly knows about all of his built heritage, as many of the information collected in the past is scattered in different national archives refusing exchange of information and documents. And finally, hasn't the term "national" heritage anyhow been replaced by "world heritage" within the last decades? But again, how can the care and protection of this heritage be managed in future, by national states and their national heritage organizations or by the international community and its official organizations?

The paper is not trying to answer those questions but to show irrelevant the terminus of national heritage nowadays became. Therefore it will dig into the history of several buildings, ensembles and towns in Kosovo and trace back their architectural history, like for Novo Brdo and Gracanica, Prizren, Decani and Peja. Additionally it will show that this is not a unique situation for a specific region, but that similar cases have happened elsewhere in Europe, too.
\end{abstract}

Keywords: Architectural Heritage, Care and Protection of Monuments, Christian Basilica, documentation and Inventory, National Monument, Ottoman Mosque, Sacral Architecture, Serbian Orthodox Church

\section{Introduction}

"Wo historische Wahrheit und Consequenz in einem Kunstwerke aufgegeben wird, wo man verstecken und bemänteln will, was seine Folgen vor aller Welt Augen weit verbreitet hat, da kann man unmöglich noch auf unbefangene Theilnahme und allgemeines Interesse Rechnung machen. Ein solches Werk wird, als das Geschöpf einer selbstsüchtigen und eit len Zeit, mit dieser untergehen"[1] The great German architect Karl Friedrich Schinkel protested such against the plans of the year 1818 to restore the Marienburg into a propagandistic German national monument. With that restoration of a former castle of the German Order in Eastern Prussia, the still very young Germany struggled hard to give itself identity. What Schinkel very clearly had foreseen is that only a history, which was not manipulated, will last.

Historic developments like this remind us on the current discussion between Albanians and Serbians on the monumental architectural heritage of Kosovo. Are the monastery churches of Deçani and Graçanica, the Patriarchate of Peja and the Church of the Virgin of Ljeviša in Prizren really Serbian monuments in their categorization as enlisted into UNESCO World Heritage under the number 724 in 2004 (Deçani) and

724 bis in 2006 (Serbian Medieval Monuments)? The official title indicates that those buildings were built as sacral buildings of the Serbs, but with the recent shifts in the political landscapes of Balkans 
now belong to the territories of Kosovo, which even makes them "endangered" heritage of the world on the "red list" of UNESCO.

Serious building archaeology from independent institutions like $\mathrm{CHwB}$, but also older research undertaken still in the Yugoslavian republic and recent publications by a new generation of Albanian scholars proof very clearly that those listed Serbian Medieval Monuments mostly are based on top or in the vicinity of older Byzantine or Early Christian basilicas. During the times of the formation of the Serbian nation in the 13th and 14th centuries, those sacral buildings, for political reasons, were transformed into Serbian orthodox monuments. When the Ottomans took over the territories in the 15 th and 16th centuries, those orthodox, as well as some other catholic churches of the region again were transformed, now into mosques. After the collapse of the Ottoman Empire, the communist politics of Tito's Yugoslavia had no great interest to reclaim those buildings for whatever church community. Therefore, scientific research was reasonably neutral. But with the beginning of the Balkan wars at the end of the 20th centry and for Kosovo in particular cumulating with the riots in spring of 2004, the issue of national heritage went out of control. Now it is on time to get back to the neutral truth and to pure knowledge beyond all ideologies.

The academic youth of Kosovo is ready for it, as current publications like

Monument, Volume I by Artan Krasniqi, published in Prishtina in 2014, show. In 2012

Edi Shukriu already tried to contribute with Kisha E Shen Prendes Prizren, unfortunately only available in Albanian language. Fejaz Drançolli went the same direction with Monumental Heritage in Kosova in 2011, alighting in content, but still weak in the English translation. With this paper I would like to thank them all and others, but in particular $\mathrm{CHwB}$, for their contribution to a future for the national monuments of Kosovo.

\section{Complex Histories}

\subsection{Serbian Medieval Monuments in Kosovo}

According to the official UNESCO brief description "the Dečani Monastery was built in the mid-14th century for the Serbian King Stefan Dečanski, and it is also his mausoleum. The church represents the last important phase of Byzantine- Romanesque architecture in the Balkan region." The ICOMOS evaluation states that "Dečani Monastery is considered one of the most important monuments of Serbian culture and history. The main characteristics of the ensemble relate to a prototype attributed to the so-called Ras School, a sty le formed in Serbia in the 12th century." Bey ond that strong Serbian context, the international experts confess: "The plan and spatial arrangement of the church are Orthodox, while the exterior appearance is based on Romanesque tradition. ... The construction lasted 8 years (1327-1335), and the master builder was Fra Vita, a Franciscan from Kotor.’'[2]
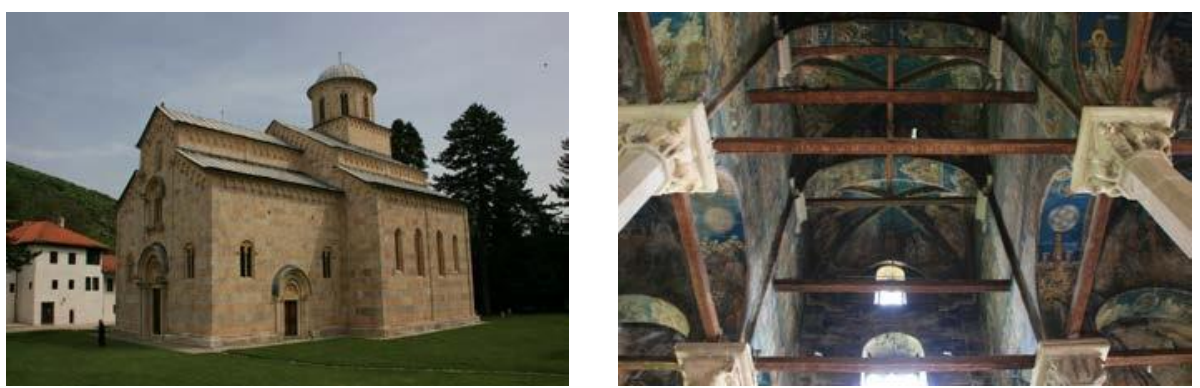

Fig. 1. Dečani Monastery Church: A fascinating contradiction between the Dalmatian coast architecture in the catholic tradition and its Serbian orthodox interior (author's photography in May 2015).

For the other three sites, summed up under "Serbian Medieval Monuments", the official brief description gives the following: "A group of three churches, the Patriarchate of Peć Monastery, Graçanica Monastery and the Church of the Virgin of Ljeviša, mainly built in the 13th and 14th 
centuries reflect with Dečani Monastery the high points of the discrete Byzantine-Romanesque ecclesiastical culture that developed in the Balkans in the 13th century under the Nemanja dynasty, ..." As outstanding universal value the following combination of values is given: "The three churches reflect a high point in the development of the discrete Balkan Palaiologos Renaissance sty le, a fusion of the eastern orthodox Byzantine sty les with western Romanesque influences, fostered by both the Serbian church and state at the height of its influence. In architectural form, [they] show the development of this style from the first appearance of the cross-in-square plan with five domes at Ljeviša, to its unique manifestation at Peć, with three separate churches united by a narthex, and its accomplished culmination at Graçanica. ..." [3]

Hence, all those sites had a more complex history before and after their high period (Serbian Medieval). Jahja Drançolli explains for Graçanica that not only visibly the monument's foundations are made with antique quarry stones from the 2 kilometers remote Roman city of Ulpiana. "It is known that Ulpiana was a prominent episcopal center under the jurisdiction of the Roman papacy in the 4th century. Material and written sources claim that a Cathedral church, the residency of the Ulpiana episcopate, existed in the area". After earthquake destruction in 518 a new cathedral church was constructed ... [4]. On the ruins of this 6th-century early Christian, three- naved basilica the 13th century church of Theotokos was built, which then the Serbian King Milutin (1282-1321) replaced by the monastery church which we see nowadays at Graçanica. "The plan, spatial arrangement, decorative wall treatment and wall paintings together have made it an emblematic structure for Balkan architecture of the 14th century reflecting the spirit of the Byzantine tradition but slightly modified by western influence.'[3].
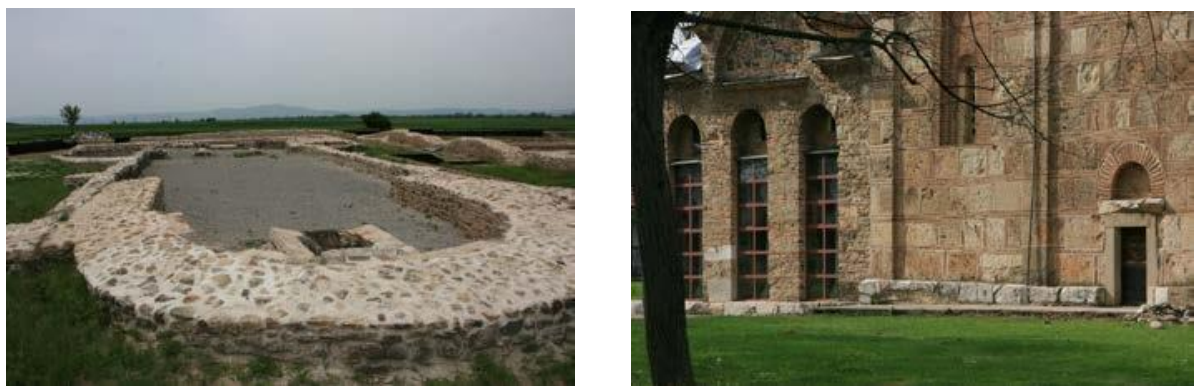

Fig. 2. Left: Remains of the cathedral church at Ulpiana; Right: Foundation wall of the monastery church of Graçanica (author's photography in May 2015).

According to the Albanian scholars, also two tales are told about the Peć (Peja) Patriarchate. In 1979 Mark Krasniqi wrote about the centuries-long protection of this building complex of the Serbian Archbishop by the Rugova highlanders, quoting Serbian historians and chroniclers as proof. Nowaday s the Patriarchate is surrounded with a brand new, three meters high wall. Besides, the entire church complex seems to be reconstructed on top of the foundations of paleo-Christian buildings of the 4th to 6th centuries $\mathrm{AD}$ [4], at least "around the churches and in caves in the Rugovo gorge, many smaller churches and hermitages developed: the Slavic name Peć means $>$ cave $<$. One of the remaining hermitages, Marko's cave, is included in the Buffer Zone" [3] of the World Heritage Site.

Finally, also for the third Serbian-Medieval Monuments enlisted as world heritage, the Church of the Virgin of Ljeviša (Kisha e Shën Prendës), the Serbian legacy is rather weak. "The plan is the starting point for a new architectural style in the Balkans, transitional between basilica and crossdomed styles ..." [3], ICOMOS expertise evaluated in 2006. Edi Shukriu in the meantime has published the reconstructions of Slobodan Nenadovic which show a classical and extent three nave basilica from the 9th or 10th century which obviously was destroyed at the end of the 12th century through Stefan Nemanjic. [5] "The church gained its present appearance after reconstruction in the early 14 th century. [3] 

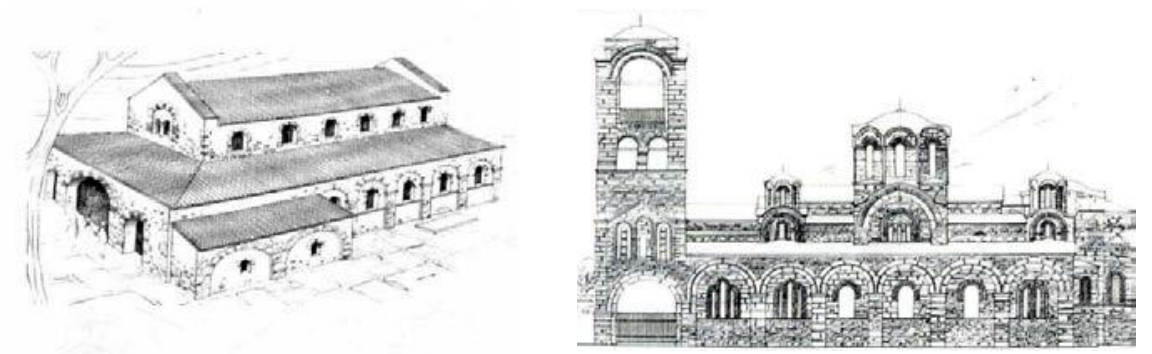

Fig. 3. Left: Prizren, Church of the Virgin of Ljeviša (Kisha e Shën Prendës), reconstruction by Slobodan Nenadovic of the 9th/10th century by zantine basilica on its site; Right: Southern elevation of the 14th century church (Edi Shukriu, Kisha e Shën Prendës Prizren, 2012).

Some times before 1756, after Turkish re-conquest, the Church of the Virgin of Ljeviša was turned into a mosque and substantial readjustments were made: apertures were closed, a minaret added to the bell tower, the walls plastered inside and in order to gain a form key the paintings were first $>$ nicked $<\ldots$ After the liberation of Prizren from the Turks, the church once again became a Christian place of workshop and was restored in 1918. Despite the substantial readjustments described above - only $30 \%$ of the original wall paintings survived - ICOMOS confirmed its authenticity in 2006. [3]

\subsection{The Catholic churches of Novobër dë and their minarets}

"When Novobërdë (Novo Brdo), was a city, London was a village", goes the saying about the incredibly rich silver mining town of the middle ages, 35 kilometers southeast of Prishtina. With the sophisticated knowledge of Saxonian mining experts and incorporated into the extent trading empire of the republic of Ragusa, Novobërdë grew in the 14th and 15th centuries to a good size town of 30.000 to 45.000 inhabitants. Its mint produced coins known as $>$ Grossidi Novoberda< causing rapid economic development within the region. $[4,6]$

For its Saxonian miners, other German craftsmen, the traders from Ragusa and various catholic settlers Novobërdë provided at least two catholic churches, one parish church and the cathedral Saint Nicholas, constructed in the 14th century, and reconstructed during the first half of the 15th. A survey report, written by the Kosova branch of CHwB in 2008, gives accurate dimensions, 30.7 meters by 23.42 meters for the cathedral. The church was converted into a mosque in 1466, when a minaret was added. The locals as well as some experts think that the cathedral with the minaret was exploited for political games in Belgrade to $>$ prove $<$ the allegations that Serb Orthodox churches were converted into mosques during the rule of the Ottoman Empire. The medievalist Jahja Drançolli argues with an extent study of the religious structure of the population that Novobërdë never was a Serbian town [4].
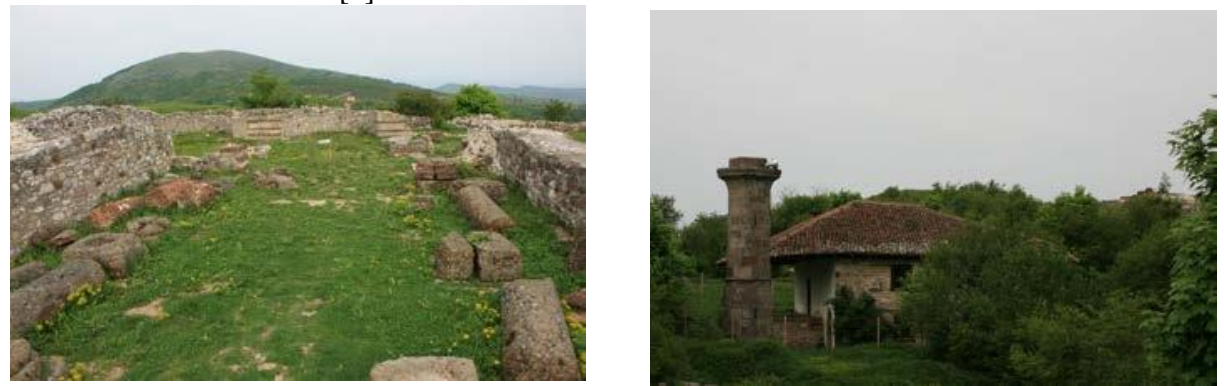

Fig. 4. Left: Remains of the catholic cathedral Saint Nicholas at Novobërdë; Right: Foundation wall of the monastery church of Graçanica (author's photography in May 2015). 


\subsection{Church and Mosque in Parthenon}

Modifications of sacral buildings for other religions than the original one are not unique nor seldom in Europe. The basilica as building type once was invented by the Romans for common jurisdiction at the forum. Still in Roman times it was adopted by Christian communities for their church services. In the late nineteenth century the basilica as building type proved its use in early industries as well lite manufacturing structure. So the basilica shifted from administrative to sacral and finally industrial use over the course of the times. [7]

Even the famous Parthenon at Acropolis in Athens had an interesting fate, before monument preservation brought him back into its "original" status. Although several times sieged and robbed he survived his first 500 years nearly unchanged. First interventions took place when he was turned into a byzantine church during the first half of the 5th century. The entrance moved to the west, whereas in the east an apse replaced the major doorway of the temple. As exonarthex the western room served the freshly installed galleries as well as the nave. The peristasis outside was enclosed with a wall of half the height and the interior was plastered and decorated with frescos (murals) and mosaics. Therefore the Parthenon survived as byzantine bishop's church without any substantial damage. Then Athens was sacked by crusaders, but later reinstalled as residence of the Romancatholic bishops.

In 1458 the Ottoman Sultan Mohammed II conquered Athens. He was educated enough not to touch the Parthenon. It is said that he gave it back to the Orthodox Church. Hence, the Parthenon later was changed into a mosque without interference of the building substance. A minaret was erected in the southern corner of the opisthodom and the ikonostasis and the altar were replaced by mimbar and mihrab. The Turkish even saved the ceiling through an additional, structural pilaster.

In 1687 the Parthenon was heavily damaged. The Venetian fleet besieged Athens and the Turks had stored their ammunition in the temple. The exploding bombs heavily damaged the cella with the famous freeze and 28 columns of the peristasis collapsed. The final destruction was caused by Lord Elgin who >stole< the famous marbles for the British Museum in 1802-03 [8].
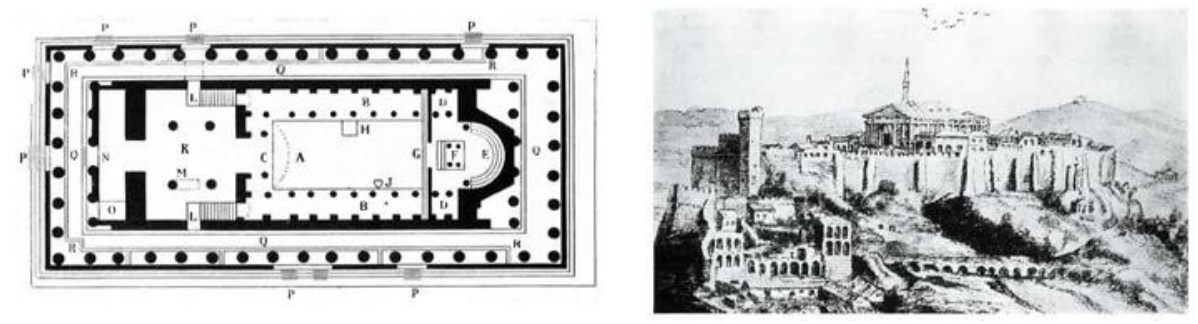

Fig. 5. Left: The Parthenon during Byzantine times, A. Michaelis, 1912; Right: The Acropolis with minaret, anony mous drawing, 1670 (Machatschek, 1961, Fig. 195 and 199).

\subsection{Athena temple and dome of Syracuse}

In the Sicilian town of Syracuse, in the 7th century AD the Christian dome was built into the magnificent and widely known temple of Athena, a 6 x 14 column peripteros from the 5 th century $\mathrm{BC}$. The temple was changed into a basilica with three naves by closing the intercolumnium of the exterior walls and opening of the cella wall into eight arcades. Inside the dome and along the Via Minerva, the columns' base, shaft, head and architrave of the antique temple still are visible [9] and articulate the uniqueness of the site. 


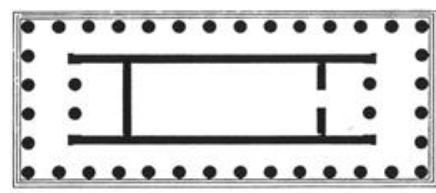

SYRANU, ATHENATEMPEL GRUNORSS

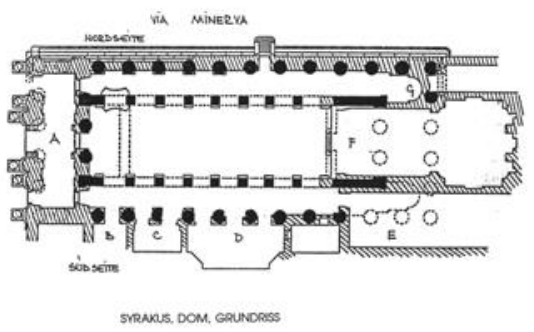

Fig. 6. Left: Plan of the antique temple of Athena and its turn into a Christian basilica; Right: Main entrance into the dome nowadays (Hannes Toifel, Caroline Jaeger-Klein, May 1990).

\section{Conclusion}

If we compare the times, when Germany tried to shape its identity by national monuments, with the current discussion in Kosovo over its >Serbian< monuments, we might learn something. The connotation of > gothic < was very negative, as long as the Gothic was considered to be the style of barbarians. When prominent writers like Johann Wolfgang von Goethe and Friedrich Schlegel pushed Gothic as truly German architecture, all of a sudden the image of the style shifted. The fancy side of the story is that the monuments used as models for German national architecture nowadays are situated no longer on German grounds. The minster of Strassburg (Strasbourg) today belongs to France, the Marienburg (Malbork) to Poland, and of course, both sites are proudly listed as national heritage of the two national states as well as UNESCO World Heritage, the Marienburg since 1997, the Strassburg minster in the zone of the Grande Île du Strasbourg since 1988.

Of course, the national state of the territory is responsible with its local administration for care and maintenance of such monuments, even if they were - at certain times - considered to be essential heritage of another nation. Kosovo has to learn this lesson quickly for its >Serbian< medieval monuments.

\section{References}

1. Huse, Norbert: Denkmalpflege. Deutsche Texte aus drei Jahrhunderten, München (2006).

2. UNESCO World Heritage List No. 724, Paris (2004), 120-123.

3. UNESCO World Heritage List No. 724 bis, Paris (2006), 141-148.

4. Krasniqi, Artan: Monument, Vëllimi I, Prishtina (2014), 63.

5. Shukriu, Edi: Kisha e Shën Prendës Prizren, Prishtina (2012).

6. Wenzel, Susanne: Das Kosovo entdecken, Berlin (2005), 63-66, 96-97.

7. Jaeger-Klein, Caroline: "Conversions in Urban History", in Baum, Martina / Kees Christiansen (ed.): City as Loft. Adaptive Reuse as a Resource for Sustainable Urban Development,Zürich, 2012, $59-66$.

8. Machatschek, Alois: "Der Parthenon von Athen - Schicksal und Denkmalpflege", in Österreichisches Bundesdenkmalamt (ed.): Österreichische Zeitschrift für Kunst und Denkmalpflege, XXI/1967 Wien 169-178.

9. Scharf, Helmut: Sizilien, Zürich und München (1986), $175 f$. 